\title{
EVALUASI IMPLEMENTASI SISTEM ZONASI PENDIDIKAN (Studi Kasus di SMP Negeri 2 dan 7 Purwokerto)
}

\author{
1'Irna Sulistiani, ${ }^{2}$ Alizar Isna, ${ }^{3}$ Sendy Noviko \\ Administrasi Publik, Fakultas Ilmu Sosial dan Ilmu Politik, Universitas Jenderal \\ Soedirman, Indonesia
}

\begin{abstract}
Since the 2017/2018 school year the Banyumas Regency government has been organizing Acceptance of New Students at the junior high school level, one of which uses the zoning system. This is motivated because the quality of education in Banyumas Regency especially at the JHS level is uneven, as evidenced by the naming of favorite and non-favorite schools in the community. Since the implementation of the zoning system in Banyumas Regency has created new problems. This study aims to evaluate the implementation of education zoning policies in JHS 2 and 7 Purwokerto based on the applicable policy guidelines and to determine the supporting and inhibiting factors of JHS 2 and 7 Purwokerto in achieving the objectives of the education zoning system policy. The method used in this research is qualitative. The selection of informants uses purposive sampling technique. Data collection uses in-depth interviews, observation and documentation study. Data analysis method used is an interactive analysis method. The results showed that JHS 2 Purwokerto as a favorite school and JHS as a non-favorite school had complied with the applicable policy guidelines, there were supporting factors which were the decentralization of power from the central government to regional governments and there were inhibiting factors namely the presence of blank spots and the desire of the community to enter favorite schools. The findings of the study are that JHS 7 Purwokerto as a nonfavorite school has not been able to capture children of good quality because it is inferior to the 15\% quota for achievement paths so that children who have good grades prefer to enroll in schools that are considered favorites. The school should also do active socialization and publication related to the achievements obtained to prospective students and parents of students, it is hoped that in this way it can generate trust to attend school at the school.
\end{abstract}

Keywords: Zoning System, Acceptance of New Students, Students

\begin{abstract}
Abstrak
Sejak tahun ajaran 2017/2018 pemerintah Kabupaten Banyumas menyelanggarakan PPDB pada jenjang SMP salah satunya menggunakan sistem zonasi. Hal ini dilatarbelakangi karena kualitas pendidikan di Kabupaten Banyumas khususnya pada jenjang SMP tidak merata, terbukti dengan adanya penamaan sekolah favorit dan non favorit yang ada di masyarakat. Sejak diterapkannya sistem zonasi di Kabupaten Banyumas menimbulkan permasalahan baru. Penelitian ini bertujuan untuk melakukan evaluasi implementasi kebijakan zonasi pendidikan di SMP N 2 dan 7 Purwokerto berdasarkan policy guideline yang berlaku serta untuk mengetahui faktor pendukung maupun penghambat SMP N 2 dan 7 Purwokerto dalam mencapai tujuan dari kebijakan sistem zonasi pendidikan. Metode yang digunakan dalam penelitian ini yaitu kualitatif. Pemilihan informan menggunakan teknik purposive sampling. Pengumpulan data menggunakan wawancara mendalam, observasi dan studi dokumentasi. Metode analisis data yang digunakan adalah metode analisis interaktif. Hasil penelitian menunjukkan SMP N 2 Purwokerto sebagai sekolah yang dianggap favorit dan SMP N 7 sebagai sekolah yang dianggap non favorit telah patuh terhadap policy guideline yang berlaku, terdapat faktor pendukung yaitudesentralisasi kekuasaan dari pemerintah pusat ke pemerintah daerah serta terdapat faktor penghambat yaitu masih adanya blank spot dan keinginan dari masyarakat untuk masuk sekolah favorit. Temuan penelitian yaitu SMP Negeri 7 Purwokerto sebagai sekolah non favorit belum mampu menjaring anak-anak dengan kualitas yang baik dikarenakan kalah dengan kuota $15 \%$ jalur prestasi sehingga anak yang mempunyai nilai yang baik lebih memilih mendaftar di sekolah yang dianggap favorit. Sebaiknya pihak sekolah juga
\end{abstract}


melakukan sosialisasi dan publikasi secara aktif terkait prestasi yang didapatkan kepada calon siswa dan orangtua siswa, melalui cara ini diharapkan mampu menimbulkan kepercayaan untuk bersekolah di sekolah tersebut.

Kata Kunci: Sistem Zonasi, PPDB, Siswa

${ }^{*}$ Penulis Korespondensi

E-mail : irnasulistiani97@gmail.com

PENDAHULUAN

Kualitas pendidikan di Indonesia saat ini tidak seimbang antarsekolah, salah satunya tampak pada penyebutan sekolah favorit dan non favorit oleh masyarakat. Penyebutan sekolah favorit dan non favorit telah menyebabkan kastanisasi sekolah, yang berimplikasi pada sistem seleksi penerimaan calon peserta didik. Pada sekolah favorit, hanya calon peserta didik baru yang cerdas, mempunyai prestasi, dan biasanya berasal dari kelompok masyarakat berada, yang bisa masuk ke sekolah tersebut. Sedangkan bagi calon peserta didik yang tidak lulus seleksi sekolah favorit, akan masuk ke sekolah yang dianggap tidak favorit. Sistem zonasi adalah sebuah kebijakan yang diterapkan oleh Pemerintah Indonesia melalui Peraturan Menteri Pendidikan dan Kebudayaan (Permendikbud), yang setiap tahunnya diperbarui. Diawali dengan Permendikbud Nomor 17 Tahun 2017 yang berlaku saat ini adalah Permendikbud Nomor 20 tahun 2019 tentang Penerimaan Peserta Didik Baru (PPDB) pada Taman KanakKanak (TK), Sekolah Dasar (SD), Sekolah Menengah Pertama (SMP), Sekolah Menengah Atas (SMA), dan Sekolah Menengah Kejuruan (SMK). Sistem zonasi merupakan kebijakan terkait seleksi calon peserta didik baru dengan memperhitungkan dan memprioritaskan perhitungan jarak terdekat tempat tinggal calon peserta didik baru dengan sekolah, dalam zonasi yang sudah ditetapkan oleh dinas pendidikan di daerah tersebut.
Menurut mantan Menteri Pendidikan dan Kebudayaan (Mendikbud) Muhadjir Effendy, tujuan sistem zonasi ialah menghilangkan dikotomi antara sekolah favorit dan nonfavorit, serta menghilangkan eksklusivitas dan diskriminasi sekolah. Sistem zonasi berupaya untuk menjadikan semua sekolah sama baiknya dari Sabang sampai Merauke, khususnya sekolah negeri. Sistem zonasi berimplikasi pada calon peserta didik baru yang diterima, baik pada sekolah favorit maupun non favorit sehingga siswa yang masuk mempunyai nilai UN yang lebih bervariatif atau heterogen. Bervariasinya nilai UN peserta didik baru yang menunjukkan heterogennya kemampuan akademik mereka, pada akhirnya akan menuntut kreativitas guru dalam mengelola proses pembelajaran di kelas. Kreativitas guru yang dimaksud, antara lain berkaitan dengan penggunaan metode-metode pembelajaran yang lebih variatif, menyesuaikan dengan kemampuan dan kebutuhan para siswa.

Implementasi sistem zonasi

masih menimbulkan masalah di hampir seluruh wilayah Indonesia. Seperti yang terjadi di Tangerang, Banten, di mana para orang tua memaksa masuk ke dalam gedung SMP 23 Pinang, lantas memaksa menemui kepala Dinas Pendidikan dan Kebudayaan Kota Tangerang, mereka kesal lantaran anaknya tidak diterima di sekolah tersebut. Sebelum implementasi sistem zonasi, kualitas pendidikan khususnya SMP Negeri di Kabupaten Banyumas belum 
terdistribusi secara merata. Hal ini dibuktikan dengan peringkat SMP Negeri berdasarkan rata-rata hasil ujian nasional. Berdasarkan data dari Dinas Pendidikan Kabupaten Tabel 1. Peringkat UN SMP Negeri di Kabupaten Banyumas Tahun 2016-2017 dan $2017 / 2018$.

\begin{tabular}{|l|lr|c|c|c|l|}
\hline \multirow{2}{*}{ No } & \multirow{2}{*}{ Nama Sekolah } & \multicolumn{3}{|l|}{ Peringkat Sekolah } \\
\cline { 3 - 7 } & & $\begin{array}{l}2016- \\
2017\end{array}$ & $\begin{array}{l}\text { Jumlah } \\
\text { Nilai }\end{array}$ & $2017-2018$ & Jumlah Nilai \\
\hline 1. & $\begin{array}{l}\text { SMPN } \\
\text { Purwokerto }\end{array}$ & 1 & 344,52 & 1 & 335,20 \\
\hline 2. & $\begin{array}{l}\text { SMPN } \\
\text { Purwokerto }\end{array}$ & 2 & 321,17 & 4 & 304,10 \\
\hline 3. & $\begin{array}{l}\text { SMPN } \\
\text { Ajibarang }\end{array}$ & 3 & 317,54 & 3 & 312,77 \\
\hline 4. & $\begin{array}{l}\text { SMPN } \\
\text { Purwokerto }\end{array}$ & 4 & 316,20 & 2 & 314,55 \\
\hline 5. & $\begin{array}{l}\text { SMPN } \\
\text { Wangon }\end{array}$ & 5 & 305,43 & - & - \\
\hline 6. & $\begin{array}{l}\text { SMPN } \\
\text { Purwokerto }\end{array}$ & - & - & 5 & 294,72 \\
\hline
\end{tabular}

Sumber: Dinas Pendidikan Kabupaten Banyumas

Tabel 1 menunjukkan lima peringkat tertinggi UN tingkat SMP di Kabupaten Banyumas dari tahun 2016-2017 yang tidak banyak berubah dan hanya dipegang oleh sekolah yang sama. Berdasarkan data di atas terlihat bahwa SMP $\mathrm{N} 2$ Purwokerto selalu menjadi peringkat pertama dalam nilai Ujian Nasional. Oleh karenanya, muncul anggapan masyarakat bahwa sekolah tersebut merupakan sekolah favorit. SMP N 7 Purwokerto juga merupakan salah satu SMP negeri di kota tersebut, tetapi SMP N 7 tidak pernah masuk dalam 5 besar peraih nilai $U N$ tertinggi, sehingga dinilai oleh masyarakat sebagai SMP negeri non favorit di antara SMP negeri di Purwokerto. Permasalahan sistem zonasi juga terjadi di Kabupaten Banyumas. Sejak dikeluarnya Permendikbud No 17 Tahun 2017, PPDB khususnya pada jenjang SMP di Purwokerto menimbulkan
Banyumas, lima besar peringkat SMP Negeri berdasarkan rata-rata hasil ujian nasional tahun 2016/2017 dan 2017/2018 dari 84 SMP di Kabupaten Banyumas adalah sebagai berikut: 
Purwokerto dalam mencapai tujuan dari kebijakan sistem zonasi pendidikan. Penelitian ini menggunakan teori evaluasi implementasi dari Ripley dan Franklin (dalam Kusumanegara, 2010: 127) terdapat dua pendekatan untuk menilai evaluasi implementasi kebijakan, yaitu perspektif complience dan perspektif what's happening. Pendekatan pertama yaitu compliance terfokus pada kepatuhan dengan pendekatan top-down memahami keberhasilan implementasi dalam arti sempit. Pendekatan ini melihat bagaimana implementor kebijakan mematuhi sesuai prosedur, jadwal, dan batasan yang dilakukan sehingga persoalannya menyangkut konsistensi antara pelaksana kebijakan di lapangan dengan policy guide yang telah diterapkan. perspektif yang kedua yaitu what's happening disebut juga sebagai pendekatan bottom-up yang memahami implementasi secara lebih luas, perspektif ini tidak mengacu hanya pada kepatuhan pada implementernya. Perspektif ini berasumsi bahwa banyak faktor yang mempengaruhi implementasi suatu program, mulai program ditetapkan sampai implementasi di lapangan. Pendekatan ini menginginkan adanya pengungkapan kejadian-kejadian dalam ranah implementasi di lapangan secara jujur dan terbuka.

\section{METODE PENELITIAN}

Metode penelitian yang
digunakan dalam penelitian ini
adalah kualitatif. Penelitian ini
dilaksanakan di SMP N 2 dan 7
Purwokerto, karena masyarakat
menganggap SMP N 2 Purwokerto
sebagai SMP favorit dan SMP N 7 di
Purwokerto sebagai non favorit di
Kabupaten Banyumas. Penelitian juga
dilaksanakan di Dinas Pendidikan

Kabupaten Banyumas. Pemilihan informan yang digunakan dalam penelitian ini adalah teknik purposive sampling. Sumber data yaitu informan, tempat dan peristiwa serta dokumen dan arsip. Metode pengumpulan data yaitu wawancara mendalam, observasi dan studi dokumentasi. Model analisis yang digunakan adalah analisis interaktif Miles B Matthew, A. Michael Huberman dan Johnny Saldana (2014).

\section{HASIL DAN PEMBAHASAN}

Jika dikaitkan dengan perpektif compliance berdasarkan teori implementasi Ripley dengan aspek yang terdiri kepatuhan terhadap prosedur pelaksanaan kebijakan, peneliti menilai bahwa para implementor baik di Dinas Pendidikan Kabupaten Banyumas, SMP Negeri 2 maupun 7 Purwokerto telah taat dan patuh terhadap prosedur yang telah ada baik berdasarkan permendikbud, perbup maupun keputusan kepala dinas pendidikan yang dijadikan sebagai petunjuk teknis dalam pelaksanaan sistem zonasi pendidikan, ketaatan dapat dilihat dari pelaksanaan PPDB yang dilaksanakan secara serentak pada Bulan Juni, penetapan kuota dari setiap zona, ketaatan terhadap prinsip-prinsip, dll. Dalam implementasinya terdapat beberapa hambatan yang dialami. Menurut Kusumanegara (2010: 127) jika derajat kepatuhan tinggi maka implementasi sudah dapat dikatakan baik, sebaliknya jika derajatnya rendah maka implementasinya dinilai buruk. Hal tersebut senada dengan artikel yang ditulis oleh Agus Dwiyanto yang berjudul Evaluasi Program dan Kebijaksanaan Pemerintah (1995: 2) yang menyebutkan bahwa adanya compliance dalam pelaksanaan 
kebijaksanaan tidak secara otomatis membawa dampak seperti yang diharapkan, kegagalan suatu program dan kebijaksanaan untuk melahirkan dampak yang diharapkan, kendati telah dilaksanakan sesuai dengan policy guidelines, disebut sebagai theory failures.

Terdapat banyak pihak yang terlibat pada saat sebelum maupun saat pelaksanaan sistem zonasi pendidikan. Keterlibatan pihak-pihak tersebut yaitu sekolah-sekolah khususnya SMP Negeri 2 dan 7 Purwokerto bisa dikatakan cukup tinggi, hal ini dikarenakan aktor-aktor dari kedua sekolah mengikuti proses musyawarah yang diselenggarakan oleh pemerintah Banyumas terkait aturan untuk PPDB yang didalamnya terdapat sistem zonasi. Selama proses PPDB juga terdapat panitia khusus tingkat sekolah yang bertugas untuk mengatur jalannya PPDB serta membantu orangtua dan calon siswa yang kesulitan melaksanakan pendaftaran secara online, maka panitia akan membantu proses pendaftaran tersebut. Dengan adanya panitia PPDB baik di SMP Negeri 2 maupun 7 Purwokerto proses pelaksanaan PPDB dapat berjalan dengan lancar.

Terkait kejelasan tujuan dari zonasi telah cukup jelas hal ini disampaikan oleh Kepala Sub Bagian Perencanaan Dinas Pendidikan Banyumas bahwa tujuan sistem zonasi pendidikan yaitu agar semua siswa baik dari golongan mampu maupun tidak mampu dapat bersekolah di sekolah negeri yang terdekat karena bisa menghemat biaya secara ekonomi, menjadikan sekolah menjadi sekolah unggulan serta meratanya siswa yang mempunyai kemampuan lebih di semua sekolah, hal yang sama juga disampaikan oleh pihak SMP N 2 dan 7 Purwokerto. Untuk mencapai tujuan dari sistem zonasi pendidikan, maka kepala sekolah SMP Negeri 2 Purwokerto yang dianggap sebagai sekolah favorit maupun kepala sekolah SMP Negeri 7 Purwokerto yang dianggap sekolah non favorit memberikan arahan kepada guru untuk lebih sabar dalam menghadapi siswa-siswi yang masuk melalui jalur zonasi dikarenakan kondisi siswa yang masuk lebih heterogen dari sebelum zonasi.

Perkembangan program yaitu perkembangan suatu program bisa diukur dari manajemen dan koordinasi dari masing-masing aktor pelaksana

saat mengimplementasikan program, Dinas Pendidikan dan sekolahsekolah negeri masing-masing aktor saling berkoordinasi dari mulai perumusan terkait penentuan zona yang dilaksanakan antara pemerintah dengan sekolah serta masyarakat, sosialisasi terkait teknis PPDB yang dilaksanakan secara online, serta petunjuk teknis yang dibuat oleh Dinas Pendidikan Kabupaten Banyumas yang selalu diperbarui setiap tahunnya dan dilaksanakan oleh seluruh sekolah yang melaksanakan sistem zonasi guna memudahkan proses PPDB. Pelaksanaan sistem zonasi pada tingkat Sekolah Menengah Pertama (SMP) di Kabupaten Banyumas sejak tahun 2017 menimbulkan banyak hambatan, penanganan permasalahan yang timbul akibat sistem zonasi salahsatunya melalui regulasi terkait PPDB jalur zonasi yang setiap tahunnya selalu mengalami perubahan. PPDB jalur zonasi pada tahun 2019 menerapkan zona kewilayahan untuk pembagian zona, hal ini dikarenakan evaluasi dari tahun sebelumnya yang menggunakan perhitungan jarak dan masih terdapat blank zone. 
Sejak pelaksanaan PPDB menggunakan jalur zonasi, SMP Negeri 2 Purwokerto yang sebelumnya menerima siswa yang mempunyai nilai Ujian Nasional (UN) tinggi atau bisa dikatakan homogen tinggi, namun setelah zonasi siswasiswi yang masuk ke SMP Negeri 2 Purwokerto mempunyai nilai yang lebih bervariasi atau heterogen bahkan terdapat siswa yang masuk dengan nilai UN 14, hal ini menyebabkan guru-guru mengubah metode mengajar dikarenakan kemampuan siswa yang kurang dan tidak seperti sebelum zonasi, jika sebelum zonasi guru-guru lebih menekankan kepada keaktifan siswasiswi di kelas sekarang peran guru yang lebih dominan. Namun, untuk perlombaan yang berada di luar sekolah, SMP Negeri 2 Purwokerto tetap mampu mempertahankan prestasinya dikarenakan masih ada siswa-siswi yang mempunyai kemampuan yang baik di bidangbidang tertentu dan masuk melalui kuota $15 \%$ prestasi. Terdapat fenomena baru di SMP Negeri 2 Purwokerto setelah dilaksanakannya sistem zonasi yaitu terdapat keterlambatan pengumpulan tugas oleh siswa-siswi sehingga guru yang harus mengejar, masih banyak siswasiswi yang nilainya tidak lulus ulangan harian sehingga harus dilakukan perbaikan, adanya siswasiswi yang bolos sekolah karena menghindari tes tertentu, tidak disiplin yaitu telat datang ke sekolah, dukungan fasilitas yang diberikan oleh orangtua kurang dikarenakan siswa yang masuk melalui jalur zonasi kebanyakan berasal dari sosial ekonomi yang berbeda, seluruh fenomena tersebut tidak terjadi pada siswa-siswi yang masuk sebelum sistem zonasi.

Kondisi yang hampir mirip juga terjadi di SMP Negeri 7
Purwokerto yang dianggap oleh masyarakat sebagai sekolah non favorit. Siswa-siswi yang masuk melalui jalur zonasi di sekolah ini mempunyai nilai Ujian Nasional (UN) yang lebih rendah dari sebelumnya, jika sebelum zonasi terdapat nilai minimal yang masuk ke sekolah adalah 21, namun setelah adanya zonasi terdapat siswa-siswi yang masuk dengan nilai UN terendah adalah 13, bahkan dalam satu kelas yang mempunyai nilai UN di bawah 20 bisa sampai 20 siswa. Awalnya sekolah memprediksi dengan adanya jalur zonasi mendapatkan siswa-siswi yang mempunyai kemampuan tinggi, namun setelah ada kuota 15\% untuk prestasi siswa-siswi yang mempunyai kemampuan tinggi diprediksi masuk ke sekolah yang dianggap favorit. Dengan kata lain dengan adanya sistem zonasi pendidikan SMP Negeri 7 Purwokerto yang dianggap sekolah non favorit lebih dirugikan, karena kondisi sosial ekonomi wilayah sekitar sekolah dari kelas menengah ke bawah serta padat penduduk.

Terkait dengan pencapaian tujuan dari sistem zonasi pendidikan yaitu pemerataan siswa antara SMP Negeri 2 dan 7 Purwokerto mempunyai pandangan yang berbeda. SMP Negeri 2 Purwokerto memandang bahwa untuk poin pemerataan siswa sudah dapat dikatakan merata hal ini dikarenakan SMP Negeri 2 Purwokerto setelah adanya sistem zonasi menerima siswa-siswi yang lebih heterogen dilihat dari bervariasinya nilai Ujian Nasional. Hal yang berbeda terjadi di SMP Negeri 7 Purwokerto yang dianggap sebagai sekolah non favorit oleh masyarakat, melalui sistem zonasi pemerataan siswa tidak bisa dikatakan merata karena setelah adanya sistem zonasi sekolah malah menerima siswa-siswi yang mempunyai nilai Ujian Nasional yang 
lebih rendah dari sebelumnya. Untuk tujuan peningkatan akses layanan pendidikan dapat dikatakan sudah tercapai karena anak bisa bersekolah di wilayah yang dekat dengan jarak tempat tinggal mereka, hal ini bisa mengurangi beban ekonomi keluarga dari kalangan menengah ke bawah. Sedangkan untuk menghilangkan dikotomi antara sekolah favorit dan non favorit jika dilihat dari pandangan masyarakat hal ini belum sepenuhnya tercapai karena masih ada siswa dan orangtua menganggap bahwa SMP Negeri 2 Purwokerto masih merupakan sekolah favorit dan SMP Negeri 7 Purwokerto sebagai sekolah non favorit.

$$
\text { Kondisi siswa-siswi yang }
$$
masuk melalui jalur zonasi juga mempunyai kemampuan yang sangat rendah, hal ini menimbulkan keluhan dari guru-guru yang mengajar. Terdapat banyak siswa-siswi SMP Negeri 7 Purwokerto yang mempunyai motivasi belajar yang sangat rendah, respon di kelas sangat rendah yang berdampak pada kondisi kelas menjadi tidak aktif. Kondisi ini menjadikan guru untuk mengubah metode pembelajaran dikarenakan kemampuan siswa yang sangat rendah, sehingga terkadang guru harus mengajar tidak sesuai dengan pedoman yang ada dan harus menjelaskan berulang-ulang terkait materi yang sama kepada siswa-siswi SMP Negeri 7 Purwokerto dengan harapan mampu memahami materi yang disampaikan oleh guru.

\section{KESIMPULAN}

Kepatuhan pelaksanaan kebijakan sistem zonasi pendidikan di SMP N 2 dan 7 Purwokerto terhadap policy guideline yang berlaku telah taat dan patuh baik terhadap prosedur pelaksanaan yaitu petunjuk teknis Dinas Pendidikan Kabupaten Banyumas, Peraturan
Bupati Banyumas Nomor 19 tahun 2019 maupun Peraturan Menteri Pendidikan dan Kebudayaan Nomor 20 Tahun 2019 serta kepatuhan terhadap jadwal pelaksanaan yang dilaksanakan secara serentak pada proses Penerimaan Peserta Didik Baru (PPDB) oleh seluruh SMP Negeri di Kabupaten Banyumas yaitu pada akhir Bulan Juni, meskipun ketaatan dikedua sekolah tersebut tinggi, namun masih terdapat permasalahan yang terjadi selama implementasi sistem zonasi pendidikan.

Terdapat faktor-faktor yang mendukung dan menghambat pencapain tujuan kebijakan sistem zonasi pendidikan di SMP N 2 dan 7 Purwokerto. Faktor pendukung pencapaian tujuan sistem zonasi pendidikan yaitu pihak SMP N 2 dan 7 dilibatkan oleh Pemerintah Kabupaten Banyumas terkait perumusan teknis pelaksanaan sistem zonasi serta Kepala Sekolah SMP Negeri 2 dan 7 Purwokerto memberikan arahan khusus kepada guru-guru untuk menghadapi siswasiswi yang kondisinya lebih heterogen setelah adanya sistem zonasi pendidikan. Faktor penghambat pencapain tujuan sistem zonasi pendidikan di SMP N 2 dan 7 Purwokerto adalah karena siswa yang masuk melalui sistem zonasi kebanyakan mempunyai kemampuan yang lebih rendah dari sebelumnya, maka guru-guru kesulitan untuk menemukan metode mengajar yang cocok untuk siswa, untuk SMP N 7 Purwokerto siswa yang masuk melalui jalur zonasi mempunyai motivasi belajar yang sangat rendah. Faktor penghambat pencapaian tujuan sistem zonasi di Kabupaten Banyumas diantaranya siswa dan orangtua yang masih beranggapan adanya sekolah favorit dan non favorit bahkan pada tahun pertama pelaksanaan PPDB terjadi 
demonstrasi serta masih adanya blank spot pada tahun pertama dan kedua pelaksanaan sistem zonasi. Hal ini berdampak pada pencapain tujuan menghilangkan dikotomi antara sekolah favorit dan non favorit belum dapat tercapai, sedangkan untuk tujuan pemerataan hanya bisa tercapai di SMP N 2 Purwokerto sebagai sekolah yang dianggap favorit, sedangkan di SMP N 7 Purwokerto selaku sekolah yang dianggap non favorit belum mampu tercapai. Untuk tujuan peningkatan akses layanan pendidikan, sudah tercapai dikarenakan anak mampu bersekolah di sekolah yang jaraknya dekat dengan rumah, sehingga mampu meringankan biaya ekonomi.

\section{DAFTAR PUSTAKA}

Abdul Wahab, Solichin. 2012. Analisis kebijaksanaan dari Formulasi ke Implementasi Kebijaksanaan Negara. Jakarta: Bumi Aksara.

Agus Purwanto, Erwan. 2012. Implementasi Kebijakan Publik Konsep dan Aplikasinya di Indonesia. Yogyakarta: Gava Media.

Arikunto, Suharsini. 2006. Metode Penelitian: Prosedur Penelitian Suatu Pendekatan Praktik. Jakarta: Rineka Cipta.

Dunn, Wiliam N. 2003. Pengantar Analisis Kebijakan Publik edisi ke-2. Jogjakarta: Gadjah Mada University Press.

Dye, Thomas R. 1981. Understanding Public Policy (4th Edition). Englewood Cliff, NJ: PrenticeHall Inc, Ltd.

Indiahono, Dwiyanto. 2009. Kebijakan Publik Berbasis Dynamic Policy Analysis. Yogyakarta: Gava Media.

Islamy, M. Irfan. 2007. Prinsip-prinsip Perumusan Kebijaksanaan Negara, Cetakan ke Empat Belas. Jakarta: PT Bina Aksara
Kusumanegara, Solahuddin. 2010. Model dan Aktor dalam Proses Kebijakan Publik. Yogyakarta: Gava Media.

Mathew, Miles B, A. Michael Huberman, Johny Saldana. 2014. Quantitatif Data Analysis: $\quad A \quad$ Methods Sourcebook Third Edition. Thousand Oaks, CA: Sage Publication Inc.

Moleong, Lexy J. 2015. Metodologi Penelitian Kualitatif. Bandung. PT Remaja Rosdakarya.

Nugroho, Riant. 2009. Analisis Kebijakan Publik. Jakarta: PT. Elex Media Komputindo Kelompok Gramedia.

Ripley, Rendal B. and Grace A. Franklin, 1986. Policy Implementation and Bureaucracy, second edition, the Dorsey Press, ChicagoIllionis.Grindle (1980)

\section{Jurnal}

Aprilia Lestari, Hermin dan Rosdiana, W. (2018). Pub Implementasi Kebijakan Penerimaan Peserta Didik Baru (PPDB) di SMA Negeri 4 Kota Madiun tahun 2017. Publika, 6(5).

Bintoro, R. F. A. (2018). Persepsi Masyarakat Terhadap Implementasi Kebijakan Zonasi Sekolah dalam Penerimaan Peserta Didik Baru (PPDB) Tingkat SMA Tahun Ajaran 2017/2018 di Kota Samarinda. Jurnal Riset Pembangunan, 1(1), 48-57

H.A.R. Tilaar. 2008. Kebijakan Pendidikan: Pengantar untuk Memahami Kebijakan Pendidikan dan Kebijakan Pendidikan sebagai Kebijakan Public. Yogyakarta: Pustaka Belajar

Juliana Macedo Reis Mercês and Profa Dra Marcia Maria Pereira Rendeiro. 2017. E-Learning 
As a Strategy For Implementation of Public Policies. International Conferences WWW/Internet, ISBN: 978-989-8533-69-2

Maryono. 2015. The Implementation of Character Education Policy At Junior High Schools And Islamic Junior High Schools In Pacitan. International Journal of Education and Research, Vol. 3 No. 5

Nurlailiyah Aris. 2019. Analisis

Kebijakan Sistem Zonasi

Terhadap Perilaku Siswa

SMP di Yogyakarta. Jurnal
Realita Vol. 17 No. 1.

Pangaribuan, Hariyanti. Implementasi

Kebijakan Sistem Zonasi

Penerimaan Peserta Didik

Baru Jenjang SMP di

Kabupaten Gesik. Prodi

Manajemen Pendidikan,

Fakultas Ilmu Pendidikan,

Universitas Negeri Surabaya

Safarah Arafinna Azizah, Wibowo

Budi Udik. (2018). Program

Zonasi di Sekolah Dasar

Sebagai Upaya Pemerataan

Kualitas Pendidikan di

Indonesia. Jurnal Lentera

Pendidikan Vol. 21 No. 2. 